\title{
Studies on intestinal digestion in the sheep
}

\section{3.* Net movement of certain inorganic elements in the digestive tract on rations containing different proportions of hay and rolled barley}

\author{
By E. PFEFFER, $\uparrow$ A. THOMPSON AND D. G. ARMSTRONG \\ Department of Agricultural Biochemistry, \\ University of Newcastle upon Tyne
}

(Received 2 I May 1969-Accepted 29 September 1969)

\begin{abstract}
I. In each of three experiments, two sheep were given diets consisting of hay, or two parts hay to one part barley or one part hay to two parts barley. Each sheep was equipped with a cannula into the rumen and re-entrant cannulas into the proximal duodenum and the terminal ileum. The rations containing barley were supplemented to adjust the intake of calcium, phosphorus, magnesium, sodium and potassium to a level similar to that in the all-hay ration. Paper impregnated with chromic oxide $\left(\mathrm{Cr}_{2} \mathrm{O}_{3}\right)$ was given twice daily by rumen fistula.

2. Amounts of crude ash and the five minerals entering and leaving the small intestine and excreted in the faeces were measured. The amounts passing through the re-entrant cannulas were adjusted to give $100 \%$ recovery of chromic oxide. The values were used to calculate the direction and net movements of the elements through the walls of the three main parts of the alimentary tract.

3. In all instances there was an extensive net secretion of $\mathrm{Na}$ and $\mathrm{P}$ between mouth and small intestine, net absorption of $\mathrm{K}$ and $\mathrm{P}$ from the small intestine and of $\mathrm{Na}$ from the large intestine.

4. The net movements of $\mathrm{Ca}$ and $\mathrm{Mg}$ were small and rather variable. In five of the six observations there was a small net secretion of $\mathrm{Ca}$ and small net absorption of $\mathrm{Mg}$ during passage of the digesta through the reticulo-rumen, omasum and abomasum. Net secretion of $\mathrm{Ca}$ and $\mathrm{Mg}$ apparently occurred in the small intestine and net absorption of $\mathrm{Mg}$ in the large intestine.

5. The only between-diet differences were small differences in net movements of $\mathrm{Na}$ and $\mathrm{K}$.
\end{abstract}

In sheep considerable amounts of inorganic elements enter the lumen of the alimentary tract in the secretions of the various digestive glands (Kay, I960; Ash, I96r ; Storry, r96r; Harrison \& Hill, r962; Taylor, r962; Scott, 1965). The direction and extent of movement of various inorganic elements across the wall of isolated sections of the digestive tract have been studied (Sperber \& Hydén, 1952; Parthasarathy \& Phillipson, 1953; Dobson \& Phillipson, 1958; Harrison, Keynes \& Nauss, I964; Scott, 1965, 1967; Care \& van't Klooster, 1965). Analyses of the digesta removed from the intestinal tract of slaughtered cattle and sheep have been used to study net movements of certain elements (van Weerden, I96r; Chandler \& Cragle, 1962; Chandler, Kesler \& Jones, 1966; Pfeffer, Bertzback \& Lenkeit, I967); such studies relate only to conditions pertaining at a moment in time. Cannulas placed in various positions in the alimentary tract of sheep, cattle and calves have been used by Oyaert $\&$ Bouchaert (I96r), Smith (1962), Goodall \& Kay (1965), Bruce, Goodall, Kay, Phillipson \& Vowles (1966), Klejmenov (1966) and van't Klooster (1967) to determine the amounts of certain inorganic elements passing through the alimentary tract over

* Paper no. 2: Br. F. Nutr. (1969), 23, 377.

$†$ Present address: Institut für Tierphysiologie und Tierernährung, Universität Göttingen, West Germany. 
extended periods of time. The studies reported in this paper relate to the amounts of calcium, phosphorus, magnesium, sodium and potassium passing into and out of the small intestine and excreted in the faeces of sheep receiving three diets.

\section{EXPERIMENT AL}

Sheep and their management. The three sheep used (B, C and $\mathrm{Rg}$ ) were adult wethers each fitted with a rumen cannula and re-entrant cannulas in the proximal duodenum anterior to the entry of the common bile and pancreatic duct and in the terminal ileum adjacent to the caecum. For further details see MacRae \& Armstrong (r969a).

Diets. The three diets used were all-hay, two parts hay to one part rolled barley and one part hay to two parts rolled barley. The chopped hay was fed to sheep B and $\mathrm{Rg}$ and the other two diets each to sheep B and C. All diets were fed at $900 \mathrm{~g}$ fresh weight per day; the sheep were fed twice daily at 09.00 and $\mathrm{I} 6.30 \mathrm{~h}$, receiving equal quantities at each feed. No food was left uneaten.

No mineral supplement was given with the hay diet but, with the aim of maintaining the same daily intakes of the elements under study when the cereal-containing diets were fed, a mineral supplement containing calcium carbonate, magnesium oxide, potassium dihydrogen phosphate, sodium carbonate and potassium chloride was prepared. This was given in amounts to supply, daily, $\mathrm{I} \cdot 2 \mathrm{I}$ and $2 \cdot 46 \mathrm{~g} \mathrm{Ca}, 0 \cdot 20$ and $0.32 \mathrm{~g} \mathrm{P}, 0.15$ and $0.36 \mathrm{~g} \mathrm{Mg}, 0.89$ and $\mathrm{r} .84 \mathrm{~g} \mathrm{Na}$ and 4.43 and $9.78 \mathrm{~g} \mathrm{~K}$ for the diet containing two parts hay to one part barley and one part hay to two parts barley respectively. Half the daily intake of the mineral supplement, contained in a paper vial, was introduced into the rumen via the fistula at each meal along with $3 \mathrm{~g}$ of chromic oxide-impregnated paper to provide an indigestible marker. Deionized water was offered $a d l i b$.

Analyses. Representative samples of foods, faeces and of digesta collected at the proximal duodenum and at the terminal ileum were analysed for crude ash, $\mathrm{Ca}, \mathrm{K}$, $\mathrm{Mg}, \mathrm{Na}$ and $\mathrm{K}$. Crude ash was determined after ashing at $600^{\circ}$. Mineral analyses were carried out on solutions prepared by ashing samples at $470^{\circ}$. The ash was dissolved in $50 \% \mathrm{HCl}$, evaporated to dryness on a water bath and after the addition of concentrated $\mathrm{HCl}$, re-evaporated to dryness and heated for a further $2 \mathrm{~h}$, again on a water bath; the residue was dissolved in warm $6 \mathrm{~N}-\mathrm{HCl}$, filtered and washed with warm water and made to volume. Ca was determined by separation as oxalate and titration with permanganate. $\mathrm{P}$ was determined colorimetrically by the vanado-molybdate procedure. $\mathrm{Mg}$ was determined by atomic absorption spectrophotometry and $\mathrm{Na}$ and $\mathrm{K}$ by flame photometry.

The techniques used in collecting the samples and preparing them for analysis, and the method used in calculating the results for the intestinal samples to give $100 \%$ recovery of added chromic oxide have been given by MacRae \& Armstrong (1969a, $b$ ). 
RESULTS

Although the hay and barley used for the three diets were from the same bulk samples, variations were found in the content of certain of the elements in the representative samples of feed taken when each diet was prepared. The relevant analyses are shown in Table I. The total daily intakes of each of the elements are given in Table 2. It can be seen from Table 2 that, while the intakes of $\mathrm{Ca}$ and of $\mathrm{K}$ were the

Table I. Mineral content of the hay and barley samples used in preparing the diets

\begin{tabular}{|c|c|c|c|c|c|c|}
\hline \multirow[b]{2}{*}{ Diet } & \multirow[b]{2}{*}{ Food } & \multicolumn{5}{|c|}{ Content of element ( $\mathrm{g} / \mathrm{I}$ oo $\mathrm{g}$ dry matter) } \\
\hline & & $\mathrm{Ca}$ & $\mathbf{P}$ & $\mathrm{Mg}$ & $\mathrm{Na}$ & $\mathbf{K}$ \\
\hline \multirow{3}{*}{$\begin{array}{l}\text { All hay } \\
2 \text { parts hay }+1 \\
\text { part barley }\end{array}$} & Hay & 0.572 & 0.328 & 0.164 & 0.332 & 2.59 \\
\hline & Hay & 0.577 & 0.398 & 0.201 & 0.440 & $2 \cdot 68$ \\
\hline & Barley & 0.063 & 0.393 & 0.137 & $0.02 \mathrm{I}$ & 0.54 \\
\hline \multirow{2}{*}{$\begin{array}{l}\text { I part hay } t \\
2 \text { parts barley }\end{array}$} & Hay & 0.612 & 0.367 & 0.194 & 0.424 & $2 \cdot 57$ \\
\hline & Barley & 0.049 & 0.390 & 0.130 & 0.044 & $0.5^{8}$ \\
\hline
\end{tabular}

Table 2. Daily intake of minerals by sheep receiving all-hay or hay-barley rations, including mineral supplements

\begin{tabular}{|c|c|c|c|c|c|c|}
\hline & & & & intak & & \\
\hline Ration & Component & $\mathrm{Ca}$ & $\mathbf{P}$ & $\mathrm{Mg}$ & $\mathrm{Na}$ & $\mathrm{K}$ \\
\hline $900 \mathrm{~g}$ hay & Hay & $4 \cdot 25$ & $2 \cdot 44$ & $r \cdot 22$ & $2 \cdot 47$ & 19.20 \\
\hline & Supplement & - & - & - & - & - \\
\hline & Total & $4 \cdot 25$ & $2 * 44$ & $I \cdot 22$ & $2 \cdot 47$ & 19.20 \\
\hline $600 \mathrm{~g}$ hay +300 & Hay & $2 \cdot 88$ & $I \cdot 99$ & $I \cdot 00$ & $2 \cdot 20$ & 13.40 \\
\hline g barley & Barley & $0 \cdot 16$ & 0.99 & 0.34 & 0.05 & $1 \cdot 37$ \\
\hline & Supplement & $1 \cdot 21$ & 0.20 & 0.15 & 0.89 & $4 \cdot 43$ \\
\hline & Total & $4 \cdot 25$ & $3 \cdot 18$ & $I \cdot 49$ & $3 \cdot 14$ & $19 \cdot 20$ \\
\hline $300 \mathrm{~g}$ hay +600 & Hay & $1 \cdot 55$ & 0.93 & 0.49 & $I \cdot 08$ & $6 \cdot 53$ \\
\hline $\mathrm{g}$ barley & Barley & 0.24 & $I \cdot 93$ & 0.64 & 0.22 & $2 \cdot 89$ \\
\hline & Supplement & $2 \cdot 46$ & 0.32 & 0.36 & $I-84$ & 9.78 \\
\hline & Total & $4 \cdot 25$ & $3 \cdot 18$ & $r \cdot 49$ & $3 \cdot 14$ & $19 \cdot 20$ \\
\hline
\end{tabular}

same on all three rations, intakes of $\mathrm{P}, \mathrm{Mg}$ and $\mathrm{Na}$ were lower on the all-hay diet than on the diets containing cereal. These differences were primarily due to the lower content of these elements in the hay used in the all-hay diet (see Table I).

The amounts of ash and of individual minerals ingested, and the amounts entering and leaving the small intestine and excreted in the faeces of the sheep fed the three diets are given in Table 3, mean values for each diet are shown in Fig. I. The values for ash ingested included the weights of $\mathrm{Cr}_{2} \mathrm{O}_{3}$ administered daily through the rumen fistula. In all experiments the amounts of ash reaching the duodenum were appreciably greater than those ingested. On the all-hay diet the net absorption of total minerals from the small intestine was less than occurred in subsequent passage of the digesta 
through the caecum and colon. With the diets containing cereal, net absorption of minerals from the small intestine exceeded that occurring in the caecum and colon.

With $\mathrm{Ca}$ (Table 3 and Fig. $\mathrm{I}$ ), in comparison with $\mathrm{P}, \mathrm{Na}$ or $\mathrm{K}$, there was comparatively little change in the net amounts of element entering or leaving the small intestine or excreted in the faeces relative to the amounts ingested. In all but one

Table 3. Daily quantities of minerals in the rations entering and leaving the small intestine and in the faeces of sheep fed all-hay or hay-barley rations

(The duodenal and ileal digesta flows have been corrected to $100 \%$ recovery of administered $\mathrm{Cr}_{2} \mathrm{O}_{3}$ )

\begin{tabular}{|c|c|c|c|c|c|c|}
\hline \multirow[b]{2}{*}{ Total ash } & \multicolumn{2}{|c|}{$900 \mathrm{~g}$ hay } & \multicolumn{2}{|c|}{$\begin{aligned} & 600 \mathrm{~g} \text { hay } \\
+ & 300 \mathrm{~g} \text { barley }\end{aligned}$} & \multicolumn{2}{|c|}{$\begin{aligned} & 300 \mathrm{~g} \text { hay } \\
+ & 600 \mathrm{~g} \text { barley }\end{aligned}$} \\
\hline & Sheep B & Sheep Rg & Sheep B & Sheep C & Sheep B & Sheep C \\
\hline In ration & 86 & 86 & 70 & 70 & 73 & 73 \\
\hline At proximal duodenum & I I I & 97 & I2I & 124 & 105 & 108 \\
\hline At terminal ileum & 88 & $8 I$ & 70 & 78 & 59 & 64 \\
\hline In faeces & 35 & 36 & 37 & 36 & 30 & 27 \\
\hline \multicolumn{7}{|l|}{ Calcium } \\
\hline In ration & $4 \cdot 25$ & $4 \cdot 25$ & $4 \cdot 25$ & 4.25 & $4 \cdot 25$ & $4 \cdot 25$ \\
\hline At proximal duodenum & $5 \cdot 28$ & $4 \cdot 30$ & $5 \cdot 36$ & $4 \cdot 79$ & 3.74 & 4.85 \\
\hline At terminal ileum & $5 \cdot 84$ & $5 \cdot 42$ & $5 \cdot 62$ & $5 \cdot 27$ & $3 \cdot 96$ & $5 \cdot 10$ \\
\hline In faeces & $4 \cdot 65$ & $4 \cdot 19$ & $5 \cdot 36$ & $5 \cdot 27$ & $4 \cdot 02$ & $3 \cdot 92$ \\
\hline \multicolumn{7}{|l|}{ Phosphorus } \\
\hline $\begin{array}{l}\text { In ration } \\
\text { At proximal duodenum }\end{array}$ & $\begin{array}{l}2 \cdot 44 \\
8 \cdot 60\end{array}$ & $\begin{array}{l}2 \cdot 44 \\
4 \cdot 60\end{array}$ & $\begin{array}{l}3 \cdot 18 \\
9 \cdot 18\end{array}$ & $\begin{array}{l}3 \cdot 18 \\
7 \cdot 48\end{array}$ & $\begin{array}{l}3 \cdot 18 \\
8 \cdot 10\end{array}$ & $\begin{array}{l}3 \cdot 18 \\
8 \cdot 62\end{array}$ \\
\hline At terminal ileum & $3 \cdot$ I I & 3.09 & $3 \cdot 19$ & 3.50 & 3.00 & $3 \cdot 60$ \\
\hline In faeces & $2 \cdot 60$ & $2 \cdot 31$ & $3 \cdot 12$ & $3 \cdot 24$ & $2 \cdot 94$ & $2 \cdot 53$ \\
\hline \multicolumn{7}{|l|}{ Magnesium } \\
\hline In ration & $1 \cdot 22$ & $I \cdot 22$ & $1 \cdot 49$ & $\mathrm{r} \cdot 49$ & $\mathrm{I} \cdot 49$ & I 49 \\
\hline At proximal duodenum & $1 \cdot 38$ & $\mathrm{I} \cdot 03$ & $I \cdot 23$ & $I \cdot I 2$ & 0.98 & $1 \cdot 28$ \\
\hline At terminal ileum & $1 \cdot 48$ & $1 \cdot 28$ & $1 \cdot 2 \mathrm{I}$ & $1 \cdot 32$ & $1 \cdot 29$ & $\mathrm{I} \cdot 02$ \\
\hline In faeces & $1 \cdot 12$ & 0.97 & $I \cdot 28$ & $I \cdot 25$ & $1 \cdot 15$ & 0.92 \\
\hline \multicolumn{7}{|l|}{ Sodium } \\
\hline In ration & $2 \cdot 47$ & $2 \cdot 47$ & $3 \cdot 14$ & $3 \cdot 14$ & $3 \cdot 14$ & $3 \cdot 14$ \\
\hline At proximal duodenum & $17 \cdot 8$ & I 4.9 & I $8 \cdot 7$ & $2 I \cdot 2$ & $20 \cdot 1$ & $r_{5} \cdot 1$ \\
\hline $\begin{array}{l}\text { At terminal ileum } \\
\text { In faeces }\end{array}$ & $\begin{array}{l}21.4 \\
0.84\end{array}$ & $\begin{array}{l}x \cdot 3 \\
0.86\end{array}$ & $\begin{array}{l}17 \cdot 1 \\
0.65\end{array}$ & $\begin{array}{l}18 \cdot 9 \\
I \cdot 25\end{array}$ & $\begin{array}{r}12.6 \\
0.73\end{array}$ & $\begin{array}{l}14.5 \\
0.68\end{array}$ \\
\hline \multicolumn{7}{|l|}{ Potassium } \\
\hline In ration & $19 \cdot 2$ & $19 \cdot 2$ & $19 \cdot 2$ & $19 \cdot 2$ & $19 \cdot 2$ & $19 \cdot 2$ \\
\hline At proximal duodenum & 16.7 & 15.4 & $16 \cdot 1$ & $17 \cdot 5$ & $17 \cdot 6$ & $22 \cdot 6$ \\
\hline At terminal ileum & $3 \cdot 25$ & $4 \cdot 91$ & $2 \cdot 50$ & $2 \cdot 70$ & $\mathbf{I} \cdot 88$ & $2 \cdot 12$ \\
\hline In faeces & $\mathrm{I} \cdot 3 \mathrm{I}$ & $I \cdot 38$ & $\mathrm{I} \cdot 35$ & 0.89 & $I \cdot 6 I$ & $\mathrm{I} \cdot 82$ \\
\hline
\end{tabular}

instance the amounts of $\mathrm{Ca}$ entering the duodenum exceeded the amount ingested; the mean value expressed as a percentage of mean intake was $I I I \cdot 1 \% \pm 5^{\circ} 9(\mathrm{SE})$. In all instances there was also a net increase in the amount of the element during passage of the digesta through the small intestine (mean value, $122.4 \% \pm 6 \cdot 2$ (SE) of intake). In four of the observations small net losses of the element occurred in passage of the digesta through the caecum and colon; in the remaining two observations there was no change. The values for $\mathrm{P}$ (Table 3 ) show, that, while virtually the same amount of the element was excreted as was ingested, there were in all instances marked gains of 
the element before the small intestine (mean value $265 \cdot 7 \% \pm 22 \cdot 0$ (SE) of intake). On the all-hay diet there were marked differences between the two sheep. In every experiment there was a very considerable net absorption of $\mathbf{P}$ from the digesta during passage through the small intestine: a much smaller loss also occurred during passage through the caecum and colon.
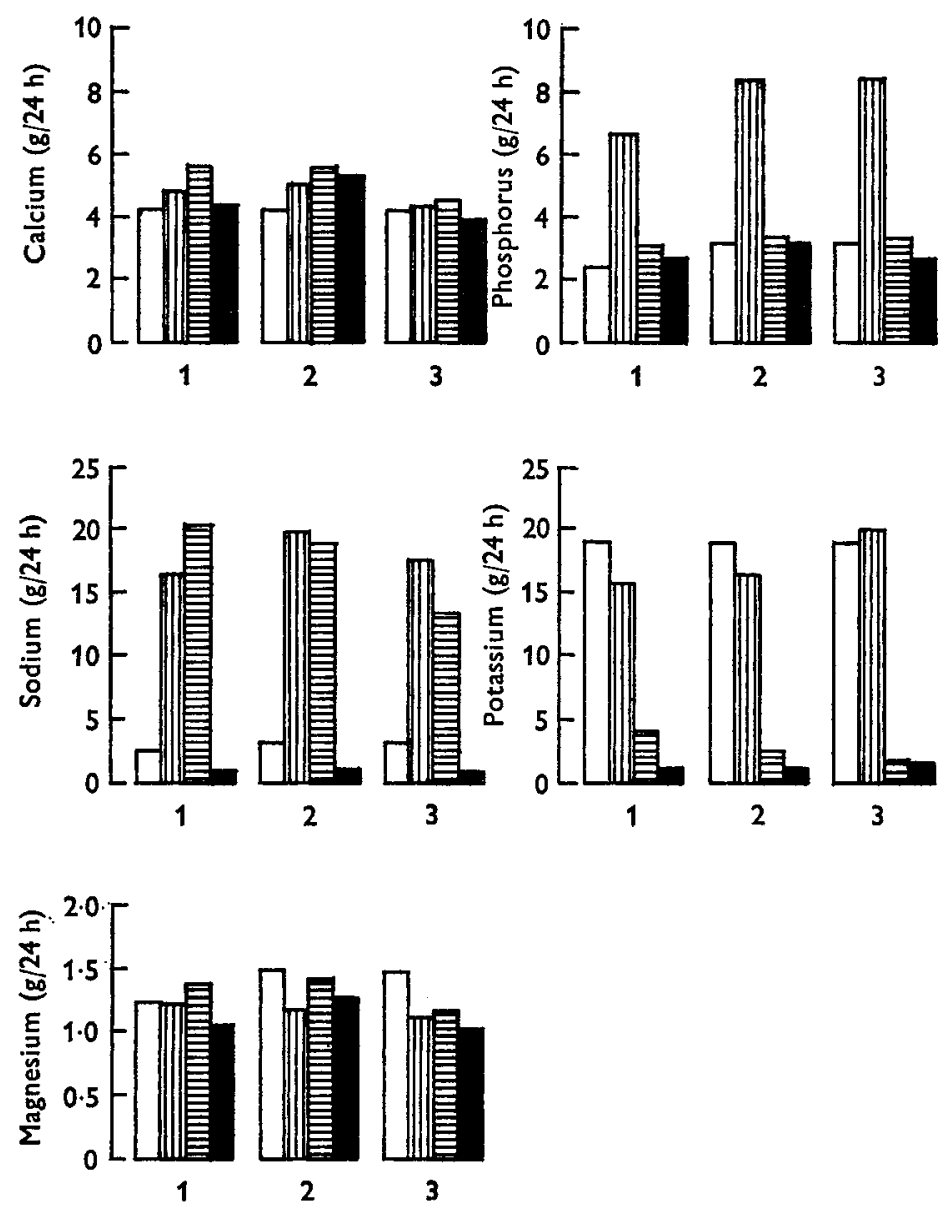

Fig. I. Daily quantities of minerals in the rations, entering and leaving the small intestine and in the faeces of sheep fed $900 \mathrm{~g}$ hay ( $\mathrm{I}$ ), $600 \mathrm{~g}$ hay $+300 \mathrm{~g}$ barley (2), and $300 \mathrm{~g}$ hay $+600 \mathrm{~g}$ barley (3). The quantities entering and leaving the small intestine have been adjusted for $100 \%$ recovery of chromic oxide. $\square$, in ration; $\square$, at proximal duodenum; $⿴$, at terminal ileum; $\boldsymbol{\square}$, in faeces.

The net movements of $\mathrm{Mg}$ like those of $\mathrm{Ca}$ in the various segments of the tract were not large, although in contrast to Ca less of the element entered the small intestine than was ingested in five of the six observations (mean value, six observations, $84.5 \% \pm 6.3(\mathrm{SE})$ of intake). However, net movements of the element in the small and large intestines were comparable in direction and in magnitude to those for $\mathrm{Ca}$. Thus in five of the six observations the amount of $\mathrm{Mg}$ reaching the terminal ileum (mean 
value, six observations, $95 \cdot 2 \% \pm 7 \cdot 4$ (SE) of intake) were greater than those entering the small intestine, and in all instances there was a small net loss of the element in passage of the digesta through the caecum and colon.

$\mathrm{Net}$ movements of $\mathrm{Na}$ in the various segments of the tract were very large. On the diets containing hay alone or two parts hay to one part barley the amounts entering the small intestine were six to seven times as great as those in the feed, on the high-barley diet five to six times as great. There was a further small net gain of $\mathrm{Na}$ in passage of the digesta through the small intestine when hay was given and very effective net absorption during passage through the caecum and colon. On the diets containing cereal, net absorption of $\mathrm{Na}$ occurred in both the small and large intestines although the extent was greatest in the latter.

For all three rations total net absorption of $\mathrm{K}$ was almost complete and in five of the six observations net absorption appeared to occur in all three parts of the digestive tract. The major site of absorption was the small intestine, as can be clearly seen from Fig. I and this is reflected in the following values for the mean amounts of the element entering and leaving the small intestine and excreted in the faeces, expressed as percentages of the amount ingested, $91 \cdot 9 \pm 5^{\circ} 45(\mathrm{SE}), 15^{\cdot} \pm \pm 2 \cdot 33(\mathrm{SE})$ and $7 \cdot 2 \pm 0 \cdot 6 \mathrm{I}(\mathrm{SE})$.

\section{DISCUSSION}

The results of this study confirm that large amounts of minerals are added to the digesta before they pass into the small intestine. Of the five elements examined, $\mathrm{Na}$ and $\mathrm{P}$ consistently showed a net secretion between mouth and proximal duodenum, as was found by Bruce et al. (1966). This finding is to be expected in view of the fact that in ruminants large volumes of saliva are continually being secreted and that, at least in Na-replete sheep, the saliva contains appreciable quantities of these two elements (Kay, I960, 1966). It has been estimated (Kay, I960) that the volume of saliva secreted daily by sheep given mixed diets of hay and concentrate lies in the range 6-I6 1 . From the results of Kay (1960) it can be calculated that mixed saliva would contain $3.0-$ $3.5 \mathrm{~g} / 1$. of $\mathrm{Na}$ and about $0.5 \mathrm{~g} / \mathrm{l}$. of $\mathrm{P}$. If in the present study a mean salivary flow of I I $1 . / 24 \mathrm{~h}$ is assumed then, if no absorption of these elements occurred before the small intestine, the amounts that might be expected to enter it over and above the amounts ingested would be $33^{-}-38 \mathrm{~g} \mathrm{Na}$ and $5.5 \mathrm{~g} \mathrm{P}$. In the present study the mean amount of Na reaching the small intestine was $15^{\circ} \circ \mathrm{g}$ and with $\mathrm{P}$ the value was $4.9 \mathrm{~g}$; some ${ }_{1} 5^{-20} \mathrm{~g} \mathrm{Na}$ was evidently absorbed before the duodenum. Dobson (1959), from studies of the uptake of ions from solutions introduced into isolated rumen sacs, has shown that absorption of the element occurs and indeed has estimated that the amount that would be absorbed daily from the reticulo-rumen approximated to $16-\mathrm{I} 7 \mathrm{~g}$. The above calculations suggest that there is no significant net absorption of $\mathrm{P}$ before the small intestine. Sperber \& Hydén ( 1952 ) showed that in general there is no considerable movement of $P$ across the rumenal wall, although Scarisbrick \& Ewer (195I) showed that the tissue is not completely impervious to inorganic $P$.

The importance of the large intestine in the absorption of $\mathrm{Na}$ has previously been reported by Hydén (1961), Goodall \& Kay (1965) and Bruce et al. (1966). The present 
studies also confirm the finding of Bruce et al. (1966) that, at least on hay-cereal rations, net absorption of the element also occurs in the small intestine.

The major site of absorption of $P$ leaving the reticulo-rumen is the small intestine, as was also reported by Bruce et al. (1966). In this connexion it is noteworthy that analyses of the intestinal contents of slaughtered sheep which had been fed on hayconcentrate rations, having a $\mathrm{Ca}$ to $\mathrm{P}$ ratio of $\mathrm{I} \cdot 6: \mathrm{I}$, showed that the ratio of these elements in the digesta in the proximal half of the small intestine was close to $0.5: 1$, whereas in the distal half it had widened to $1 \cdot 3:$ I (Pfeffer et al. 1967). Similar findings have been reported from analyses of intestinal digesta in cows (van't Klooster, 1967). Even if allowance is made for the small net secretion of $\mathrm{Ca}$ into the small intestine such as that observed in the present studies, our results would imply that most of the $\mathrm{P}$ absorption from the small intestine occurs in the proximal part; it is in this region that $\mathrm{pH}$ values are low (Phillipson \& Storry, $\mathrm{I}_{965}$ ). Kay (1969) has commented on the possible role of phosphate in transporting hydrogen ions across the intestinal wall of the sheep.

Although small amounts of $\mathrm{K}$ are contained in mixed saliva (Kay, 1966 ; Scott, 1967 ), in the present study only in one of the six observations was a net secretion of the element observed before the small intestine. Scott (1967) has shown that $\mathrm{K}$ is absorbed from the rumen in amounts proportional to the concentration of the element in the rumen fluid. It is clear that, at least in the present studies, the major site for net absorption of $\mathrm{K}$ is, however, the small intestine; this is in agreement with the findings of Bruce et al. (1966).

The small gains in $\mathrm{Ca}$ in the digesta flowing through the reticulo-rumen and particularly through the small intestine suggest that in both sites there may be small net secretions of Ca. Storry (196I) showed that small amounts of $\mathrm{Ca}$ are found in mixed saliva and in the bile and pancreatic juices of the sheep. In studies using the isolated reticulo-rumen sac of anaesthetized sheep, Phillipson \& Storry (1965) found the rumen epithelium relatively impermeable to $\mathrm{Ca}$. Using isolated loops of small intestine in conscious sheep, these workers also showed that $\mathrm{Ca}$ was absorbed from the upper jejenum and middle of the small intestine, but not from the duodenum and lower ileum.

In the studies of Phillipson \& Storry $(1965)$ the rumen epithelium appeared to be relatively impermeable to $\mathrm{Mg}$ as well as to $\mathrm{Ca}$ although these workers make reference to small but statistically significant losses of $\mathrm{Mg}$ through the epithelium in certain of their experiments. Care \& van't Klooster (1965) observed a net absorption of the element in in vivo experiments with an isolated reticulo-rumen. Certainly it would appear from the present studies that a small net absorption of $\mathrm{Mg}$ can occur from the reticulo-rumen, omasum or abomasum notwithstanding that saliva contains measureable amounts of the element (Storry, 196r). The experiments of Phillipson \& Storry (1965) with isolated loops of small intestine suggested that absorption of $\mathrm{Mg}$ could occur throughout the small intestine although it was noted that endogenous secretion of $\mathrm{Mg}$ also occurred in all parts. Bile and pancreatic juices contain significant amounts of $\mathrm{Mg}$ (Storry, $196 \mathrm{I}$ ). In the experiments reported here it would appear that, with the diets given, endogenous secretion exceeded absorption over the small intestine as a 
whole. It should be emphasized that the small net movements of $\mathrm{Ca}$ and of $\mathrm{Mg}$ observed in the tract may be of doubtful significance in view of the possible errors associated with their derivation, it will be recalled that all values for flow into and out of the duodenum were corrected for $100 \%$ recovery of chromic oxide.

The only between-diet differences in the net movements of a particular element were found with $\mathrm{Na}$ and $\mathrm{K}$. For both elements, as the proportion of barley in the diet increased, the amounts leaving the small intestine decreased, the net secretion of $\mathrm{Na}$ into the small intestine on the all-hay diet became a net absorption on the cerealcontaining diets and net absorption of $\mathrm{K}$ increased; total net absorption of both elements from the caecum and colon declined. It is not possible to say whether these differences were due to the replacement of hay by the more digestible barley, and hence to smaller quantities of digesta entering the intestine, or to the fact that as the proportion of barley increased so did the contribution of the mineral supplement to the supply of these minerals.

\section{REFERENCES}

Ash, R. W. (г961). F. Physiol., Lond. r57, I85.

Bruce, J., Goodall, E. D., Kay, R. N. B., Phillipson, A. T. \& Vowles, L. E. (1966). Proc. R. Soc. B I66, 46.

Care, A. D. \& van't Klooster, A.Th. (1965). F. Physiol., Lond., 177, 174.

Chandler, P. T. \& Cragle, R. G. (1962). Proc. Soc. exp. Biol. Med. III, 43 I.

Chandler, P. T., Kesler, E. M. \& Jones, G. M. (I 966). F. Anim. Sci. 25, 64.

Dobson, A. (1959). F. Physiol., Lond. 146, 235.

Dobson, A. \& Phillipson, A. T. (1958). F. Physiol., Lond. 140, 94.

Goodall, E. D. \& Kay, R. N. B. (1965). F. Physiol., Lond. 176, i2.

Harrison, F. A. \& Hill, K. J. (1962). F. Physiol., Lond. 162, 225.

Harrison, F. A., Keynes, R. D. \& Nauss, A. H. (1964). F. Physiol., Lond. 171, 18 P.

Hydén, S. (196I). K. LantbrHögsk. Annlr. 27, 273.

Kay, R. N. B. (1960). F. Physiol,, Lond. 150, 5 I 5.

Kay, R. N. B. (1966). Wld Rev. Nutr. Diet. 6, 292.

Kay, R. N. B. (1969). Proc. Nutr. Soc. 28, r40.

Klejmenov, N. I. (1966). TagBer. dt. Akad. LandwWiss. 85, p. 283.

MacRae, J. C. \& Armstrong, D. G. (1969a). Br. J. Nutr. 23, 15.

MacRae, J. C. \& Armstrong, D. G. (I $969 b$ ). Br. F. Nutr. 23, 377.

Oyaert, W. \& Bouchaert, J. H. (196I). Res. vet. Sci. 2, 4 I.

Parthasarathy, D. \& Phillipson, A. T. (1953). F. Physiol., Lond. r21, 452.

Pfeffer, E., Bertzback, J. \& Lenkeit, W. (1967). Z. Tierphysiol. Tierernähr. Futtermittelk. 22, I 5.

Phillipson, A. T. \& Storry, J. E. (I965). F. Physiol., Lond. 18x, I30.

Scarisbrick, R. \& Ewer, T. K. (I 95I). Biochem. F. 49, lxxix.

Scott, D. (1965). Q. Fl exp. Physiol. 50, 3 I2.

Scott, D. (1967). Q. Fl exp. Physiol. 52, 382.

Smith, R. H. (1962). Biochem. F. 83, 151 .

Sperber, J. E. \& Hydén, S. (1952). Nature, Lond. I69, 587.

Storry, J. E. (1961). Nature, Lond. 190, 1 197.

Taylor, R. B. (1962). Res. vet. Sci. 3,63 .

van Weerden, E. J. (1961). F. agric. Sci., Camb. 56, 317.

van't Klooster, A.Th. (1967). Meded LandbHoogesch., Wageningen 67, 5. 